Ireneusz MILEWSKI

(Gdańsk, UG)

\title{
KILKA UWAG O ROLI BISKUPA W MIEŚCIE PÓŹNOANTYCZNYM (na przykładzie prowincji wschodnich)*
}

Wielokrotnie rozpisywano się już na temat roli biskupa w społeczeństwie późnoantycznym podnosząc wiele związanych z tym kwestii ${ }^{1}$. Przygotowując jednak niniejszy artykuł nie chciałem, aby był on jedynie powtórzeniem powszechnie znanych już i wielokrotnie cytowanych w literaturze opinii definiujących rolę biskupów w życiu publicznym w cesarstwie późnorzymskim. Dlatego też poza krótkim i ogólnym omówieniem głównych przejawów aktywności publicznej biskupów w interesującym mnie okresie, chciałbym skupić swą uwagę tylko na jednym wątku, a mianowicie na próbie udzielenia odpowiedzi na pytanie, czy niektóre spośród obszarów aktywności publicznej biskupów wschodniorzymskich w późnej starożytności, można uznać za kontynuację antycznego, żeby nie powiedzieć pogańskiego, modelu euergesji. Udzielenie odpowiedzi na to zapytanie będzie kluczowe dla właściwego zrozumienia roli biskupa w społeczeństwie późnoantycznym.

Do początku IV wieku funkcje biskupa ograniczały się przede wszystkim do spraw gminy, której przewodzil, podległego mu duchowieństwa oraz świeckich chrześcijan. Sytuacja ta diametralnie zmieniła się po roku 313, kiedy władcy, w tym przede wszystkim Konstantyn Wielki, realizując nową politykę

* Niniejszy artykuł stanowi jedynie skrótowe omówienie głównych wątków składających się na interesującą nas tu problematykę. Pełny tekst zamieszczony zostanie $w$ jednym $z$ rozdziałów przygotowywanej rozprawy habilitacyjnej poświęconej wczesnobizantyńskim dostojnikom kościelnym.

${ }^{1}$ Por. przede wszystkim S. Longosz, Kapłaństwo w starożytności chrześcijańskiej (materiały bibliograficzne), VoxP 13-15 (1993-1995) z. 24-29, 499-555; zob. także: A. Avramea, Les constructions profanes d'évêque d'après l' épigrahie et les textes d'Orient, w: Actes du XI Congrès International d'Archéologie Chrétienne, vol. I, Roma 1989, 829-835; D. Feissel, L'évêque, titres et fonctions d'après les inscriptions grecques jusqu'au VI siècle, w: tamże, s. 801-826; W. Liebeschuetz, The Rise of the Bishop in the Christian Roman Empire and the Successor Kingdoms, ,Electrum” 1 (1997) 113-125; K.L. Noethlichs, Materialien zum Bischofsbild aus den spätantiken Rechtsquellen, JACh 16 (1973) 28-59; R. Lizzi-Testa, The Bishop Vir Venerabilis: Fiscal Privileges and Status Definition in Late Antiquity, „Studia Patristica” 34 (2001) 125-144 i wiele innych, których nie sposób tu wymienić. 
religijną państwa, rozpoczęli proces, którego jednym ze skutków było włączenie biskupów w coraz liczniejsze obszary działalności publicznej. Dostrzegamy oczywiście wielotorowość procesu wzrostu roli biskupa w społeczeństwie późnoantycznym. Z jednej bowiem strony, stan ten był skutkiem uzyskania przez Kościół szeregu przywilejów od państwa; z drugiej zaś strony, co w tym konkretnym przypadku wydaje się ważniejsze, poszczególni dostojnicy kościelni, $\mathrm{z}$ racji pełnionych funkcji duszpasterskich oraz przewodząc sporym rzeszom chrześcijan, a w wielkich miastach nawet dziesiątkom tysięcy dusz, niejako poza kontrolą państwa urastali do rangi liderów lokalnych społeczności. W biskupach, posiadających szereg uprawnień nadanych im przez państwo, mieszkańcy coraz częściej upatrywali swych opiekunów, a miasta swych skutecznych obrońców przed nadużyciami ze strony urzędników. O wzroście roli biskupa w miastach późnoantycznych zadecydowała również prowadzona przez nich działalność dobroczynna.

Doszukując się genezy znaczenia biskupów w mieście późnoantycznym, z pewnością istotnym będzie również wskazanie na ich pochodzenie społeczne oraz związane $z$ tym zaplecze materialne. Nie bez znaczenia był również charakter miasta, w którym sprawowali oni swój urząd, liczba chrześcijan, którym przewodzili oraz wielkość populacji miejscowych pogan i żydów, co miało wymierny wpływ na tak zwany „klimat religijny”. Istotnym było również usytuowanie miasta (któremu biskup pasterzował) na mapie Imperium, gdyż to w mieście oddalonym od wielkich centrów politycznych łatwiej można było osiągnąć pozycje nieformalnego lidera, w mieście czasami zapomnianym, borykającym się na co dzień z podstawowymi problemami, w mieście o którym urzędnicy przypominali sobie dopiero wówczas, kiedy zbliżał się termin płacenia podatków. Szereg więc uwarunkowań złożyło się na ugruntowanie potęgi urzędu biskupiego w miastach późnoantycznych. Jeśli biskup sprawował swój urząd w mieście będącym ważnym ośrodkiem administracji w prowincji, nie mówiąc już o stolicy, wówczas z reguły odgrywał on również pewną rolę polityczną w państwie.

Znaczenie późnoantycznego biskupa, jako lidera lokalnej społeczności, nie pojawiło się jednak ex nihilo. Do pewnego bowiem stopnia w zjawisku tym dopatrujemy się kontynuowania fundamentalnych zasad ustrojowych, jakie panowały w miastach cywilizacji grecko-rzymskiej, w których to wysokie funkcje publiczne pełnili miejscowi notable. Chrześcijaństwo jednak również w tej mierze zachwiało antycznym porządkiem. Mianowicie w małych miastach, poza miejscowymi notablami, na urzędy biskupie zaczęto wynosić również ludzi pochodzących z dolnych warstw społeczeństwa, często mnichów, ludzi bez majątku i koneksji na szczeblach władzy, nie mających zbyt wiele do zaoferowania swym owieczkom, poza pobożnością, i tak często akcentowanym przez ustawodawcę świeckiego, biskupim poczuciem sprawiedliwości. Ludzie ci jednak, jak wskazują przekazy źródłowe, najczęściej nie potrafili odnaleźć się w realiach 
politycznych i ekonomicznych późnego cesarstwa, a tym samym również być przydatnymi, jeśli zachodziła potrzeba ingerencji w życie publiczne.

\section{OGÓLNA CHARAKTERYSTYKA PUBLICZNEJ DZIAEALNOŚCI BISKUPÓW}

Interesującą nas tu problematykę możemy uszeregować w trzy grupy. Do pierwszej zaliczymy te przejawy aktywności biskupiej, które wynikały z pełnionych przez nich funkcji pasterskich. Związane $\mathrm{z}$ tym było między innymi (choć również nie do końca) prowadzenie akcji dobroczynnej, fundamentalne działanie mające nie tylko pozytywne i wymierne skutki dla korzystających z niej osób, lecz również służące wzrostowi prestiżu i znaczenia biskupa w społeczeństwie. Na akcję dobroczynną składała się między innymi dystrybucja żywności, odzieży, pieniędzy, prowadzenie instytucji dobroczynnych, odwiedzanie więźniów itp.

Do drugiej grupy zaliczymy te przejawy działalności biskupiej, które były skutkiem otrzymania przez biskupów szeregu przywilejów od państwa, umożliwiających im aktywny udział w życiu publicznym. Kto wie, choć źródła milczą na ten temat, być może przydzielenie biskupom szeregu uprawnień z zakresu życia publicznego miało w zamierzeniu ustawodawcy korzystnie wpłynąć na skuteczniejsze administrowanie w prowincjach. Coraz częstsze ingerowanie biskupów w życie publiczne w cesarstwie późnorzymskim wypływało również ze wzrostu jego prestiżu społecznego, co w pewnej mierze było skutkiem nadania biskupom szeregu przywilejów w okresie zaledwie kilku lat ${ }^{2}$. Dla wzmocnienia pozycji duchowieństwa $w$ interesującym nas okresie nie bez znaczenia była również postępująca chrystianizacja państwa, kiedy to wraz z powiększaniem się szeregów chrześcijan wpływ biskupa obejmował coraz liczniejsze rzesze ludzkie.

Do grupy trzeciej zaliczyć możemy tę działalność biskupów, która w naszej opinii stanowi kontynuację antycznego modelu euergesji (o czym poniżej).

Do najważniejszych przywilejów, jakie zostały nadane dostojnikom kościelnym w okresie późnego antyku, należy przywilej rozsądzania spraw i ferowania wyroków (audientia episcopalis) ${ }^{3}$. Do początku IV wieku sądownicza działal-

${ }^{2}$ Por. W. Eck, Der Einfluss der konstantinischen Wende auf die Auswahl der Bischöfe in 4. und 5. Jahrhundert, Chiron 1978, vol. 8, s. 563.

${ }^{3}$ Por. m.in.: A. Steinwenter, Audientia episcopalis, RACh I, 1950, 915-917; J. Gaudemet, L'Église dans l'empire Romain (IV-V s.), Paris 1958, 229-240; H. Jaeger, Justinian et „l'épiscopalis audientia”, RHDE (,Revue histoire de droit francais et étranger”) 38 (1960) 214-262; H.I. Bell, The Episcopalis audientia in Byzantine Egypt, „Byzantion” 1 (1924) 139-144; R. Bagnall, Egypt in Late Antiquity, Princeton 1993, 225; J. Srutwa, Episcopalis audientia w Afryce Pótnocnej, RTK 28 (1981) z. 4, 183-187. 
ność biskupów ograniczała się tylko do środowiska, któremu przewodzili: podległego kleru i chrześcijan świeckich, lecz tylko w tych sprawach (i w dodatku nie karnych), które nie wychodzily poza krąg chrześcijan (1Kor 6, 1-6). Od czasów Konstantyna Wielkiego istniała możliwość oficjalnego zwracania się do biskupa jako do sędziego w przypadku większości spraw cywilnych. Dopuszczano nawet możliwość przenoszenia spraw wszczętych w trybunale świeckim do trybunałów biskupich (ad episcopale iudicium), o ile jedna ze stron domagała się tego. Wydany przez biskupa wyrok (sententiae episcoporum) był uznawany przez państwo ${ }^{4}$, a jego egzekwowaniem zajmowały się odpowiednie organy w prowincji ${ }^{5}$. Działalność sądownicza biskupów stanowiła z pewnością uzupełnienie skorumpowanego sądownictwa cywilnego ${ }^{6}$, choć wiemy, iż plaga korupcji nie ominęła również biskupich trybunałów.

Czy inne źródła, poza ustawodawstwem cesarskim, potwierdzają pełnienie przez biskupów wschodniorzymskich funkcji sądowniczych? Tak, choć tylko sporadycznie $^{7}$. Z relacji Teodoreta z Cyru, opisującego działalność sądowniczą Abramesa, biskupa Karrai, wynika, iż całymi dniami rozsądzał on spory sądowe, jednych nakłaniając, innych przymuszając do przyjęcia konkretnego stanowiska ${ }^{8}$. Podobnie było również w przypadku Epifaniusza, biskupa cypryjskiej Salaminy, który również czasami spędzał cały dzień na rozsądzaniu spraw9 ${ }^{9}$. Powszechnie znane są róenież wypowiedzi św. Augustyna, który sprawowanie przez siebie funkcji sądowniczych postrzegał jako zajęcie niewdzięczne i czasochłonne ${ }^{10}$.

Dlaczego biskupom w okresie późnej starożytności powierzono tak wielkie uprawnienia w dziedzinie sądownictwa? W rozporządzeniach cesarskich nadających dostojnikom kościelnym wyżej wymienione uprawnienia, ustawodawca wskazuje na dostojeństwo i uczciwość biskupią. Na pewno jednak nadanie tych przywilejów biskupom dodatkowo wzmacniało ich znaczenie w społeczeństwie i strukturach administracyjnych państwa. Otwartym pozostaje oczywiście inne

${ }^{4}$ Por. CTh I 27, 1-2; CJ I 4, 8; Const. Sirmondiana, I; Sozomenus, HE I 9.

5 Por. Sozomenus, HE I 9.

${ }^{6}$ Por. M. Mac Mullen, Corruption and Decline of Rome, New Haven 1988, 148-167; A.H.M. Jones, LRE, I, s. 496-497.

7 Niewiele na ten temat odnajdujemy również w materiale papirologicznym, por. R. Bagnall, dz. cyt., s. 195 i 224-225; tenże, Church, State and Divorce in Late Roman Egypt, w: Florilegium Columbianum. Essays in Honour of Paul Oskar Krsteller, ed. K.L. Selig - R. Somerville, New York 1987, 58-59; L. Mitteis - U. Wilcken, Grundzüge und Chrestomathie der Papyruskunde, Leipzig Berlin 1912, 121.

${ }^{8}$ Por. Theodoretus, Historia religiosa 17, 8; zob. takze Joannes Chrysostomus, De sacerdotio III 14.

${ }^{9}$ Por. Vita Epiphanii 55, PG 41, 148.

${ }^{10}$ Por. A.G. Hamman, Życie codzienne w Afryce Pótnocnej w czasach św. Augustyna, tłum. M. Stafiej-Wróblewska, Warszawa 1989, 215nn. 
pytanie, mianowicie kwestia merytorycznego przygotowania biskupów do pełnienia tych funkcji i ferowania przez nich zgodnych z prawem wyroków.

Kompetencje sądownicze biskupów zostały jednak ograniczone już w końcu IV wieku ${ }^{11}$. W jaki sposób należałoby tłumaczyć ten fakt? Posiadane przez nas źródła nie pozwalają niestety na udzielenie odpowiedzi na to pytanie. Być może, a wydaje się to najbardziej prawdopodobnym wytłumaczeniem, problem leżał w wadliwości orzeczeń ferowanych przez biskupów, co w większości przypadków musiało być skutkiem nieznajomości przez nich prawa. Niewielu przecież spośród nich miało do pomocy ludzi obeznanych z prawem ${ }^{12}$. Z pewnością również orzekane przez biskupów wyroki, nie zawsze były bezstronne; można przypuszczać, iż nie raz w sporze brali oni stronę swych stronników, którym jako biskupi przewodzili, tępiąc tym samym tak zwanych heretyków, nie mówiąc już o poganach, manichejczykach czy żydach. Żródła donoszą również o szerzącej się korupcji w biskupich trybunałach ${ }^{13}$.

Otwartym, ze względu na brak danych, pozostaje pytanie, w jaki sposób i z jakim skutkiem działalność sądowniczą sprawowali pasterze wielkich miast, jak Konstantynopol, Antiochia czy Aleksandria, czy nawet mniejszych jak Nazjanz czy Cezarea Kapadocka. Być może w przypadku wielkich miast, ze względu na to, iż były one dużymi ośrodkami administracji państwowej, funkcje te częściej pełnili tam urzędnicy świeccy.

Źródła milczą również o reakcjach duchowieństwa na stopniowe ograniczanie ich kompetencji sądowniczych. W wielu przypadkach z pewnością było to traktowane przez duchownych jako uwolnienie od tego ciężaru. Zmniejszenie ilości rozpatrywanych spraw sądowych pomniejszało zarazem dochody uzyskiwane przez nich $z$ tego tytułu. Innym, ważniejszym, skutkiem było zmniejszenie wpływu biskupów na społeczeństwo.

Ważnym uprawnieniem, podnoszącym prestiż biskupów, było przyznanie im prawa do wyzwalania niewolników (tzw. manumissio in ecclesiae). Czynności tej dokonywano w kościele w obecności wiernych ${ }^{14}$. Czasami przy wyzwalaniu niewolników biskupi musieli współdziałać z urzędnikami państwowy$\mathrm{mi}^{15}$.

Do obowiązków biskupich w tym czasie należało również odwiedzanie więźniów oraz nadzór nad warunkami, w jakich byli oni przetrzymywani ${ }^{16}$.

${ }^{11}$ Por. chociażby: CJ I 4, 7; CTh I 27, 2; Novellae Valentiniani XXXV; CJ I 4, 29.

12 „Asesorzy” i ,scholastycy” na dworach biskupich, por. Cyrillus Scythopolitanus, Vita Sabae 75; Vita Euthymii 3 (transl. by R. M. Price, ed. Lives of the Monks of Palestine, Michigan 1991); Zacharias Rhetor, HE VII 1 (Die sogenannte Kirchengeschichte des Zacharias Rhetor, hrsg. von K. Ahrens - G. Krueger, Leipzig 1899); Vita Epiphanii 55, PG 41, 148; Sozomenus, HE VII 37.

${ }_{13}$ Por. Socrates, HE VI 37; Vita Epiphanii 55, PG 41, 148.

${ }^{14}$ Por. CJ I 13, 1; CTh IV 7, 1; Sozomenus, HE I 9.

15 Por. CJ I 4, 14; CJ I 3, 54 (9).

16 Por. CJ I 4, 9; I 4, 22-23. 
Biskupi uczestniczyli również w organizacji życia publicznego: od 409 r. przysługiwało prawo do sprawowania urzędu defensora civitatis ${ }^{17}$. Biskupi posiadali również prawo współdecydowania o tym, kto obejmie urząd defensora ${ }^{18}$ oraz „ojca miasta” (pater civitatis) ${ }^{19}$.

O znaczeniu i prestiżu urzędu biskupa świadczy nadzorowanie przez nich rzetelności urzędników prowincjonalnych, w tym między innymi informowanie cesarza o pobieraniu przez urzędników zawyżonych opłat w prowincjach, szczególnie wtedy, kiedy praktykę tę tolerował namiestnik ${ }^{20}$. Biskupi wraz $\mathrm{z}$ miejscowymi primates mieli również powiadamiać cesarza o przypadkach nieuczciwego wzbogacania się urzędników w prowincjach ${ }^{21}$.

\section{PUBLICZNA DZIAEALNOŚĆ BISKUPÓW JAKO KONTYNUOWANIE ANTYCZNEJ EUERGESJI}

Przejdziemy teraz do drugiej części niniejszego komunikatu, w której podejmiemy się próby udzielenia odpowiedzi na pytanie, czy niektóre z przejawów aktywności publicznej biskupów wschodniorzymskich w interesującym nas okresie możemy uznać za kontynuację antycznego modelu euergesji. Dla większości historyków starożytności, którzy nie zajmują się antycznym chrześcijaństwem, oczywiste będzie stwierdzenie, iż euergetyzm, choć w wielu przypadkach w zmienionej formie, musiał nadal być praktykowany w późnej starożytności ${ }^{22}$. Jest to stwierdzenie prawidłowe, wbrew opiniom wielu, którzy większość przejawów aktywności publicznej biskupów, w tym przede wszystkim prowadzenie działalności dobroczynnej, wiążą z praktykowaniem chrześcijańskiej caritas. Przypomnijmy jednak, iż uczestnictwo dostojników kościelnych w życiu publicznym wychodziło daleko poza ówczesne ramy ich zwyczajowej działalności pasterskiej ${ }^{23}$. Czynne uczestnictwo w życiu publicznym, partycypowanie w kosztach związanych $\mathrm{z}$ tą aktywnością, a nawet do pewnego stopnia dokarmianie biednych mieszkańców miast, miało natomiast swój antyczny, pogański rodowód.

${ }^{17}$ Por. CJ I 55, 8; zob. MAMA (Monumenta Asiae Minoris Antiqua) III 197.

${ }^{18}$ Por. CJ I 55, 8; Novelle Iustiniani XV.

${ }^{19}$ Por. Novelle Iustiniani CXXVIII 16.

${ }^{20}$ Por. tamże, LXXXVI 9.

21 Por, tamże, CXXXIV 3.

${ }^{22}$ Tę opinię zdaje się kwestionować między innymi W. Liebeschuetz (dz. cyt., s. 116-117), który utrzymuje, iz praktykowanie euergesji (między innymi wskutek kryzysu ekonomicznego) uległo załamaniu w połowie III wieku, a jej miejsce zajęła dobroczynność kościelna. W twierdzeniu tym jest oczywiście sporo racji, mimo to jednak, ów antyczny model eurgesji nadal był praktykowany w miastach w interesującym nas okresie właśnie przez biskupów, najczęściej rekrutujących się spośród lokalnych notabli.

${ }^{23}$ Por. A. Avramea, dz. cyt., s. 829-835; D. Feissel, dz. cyt., s. 801-808. 
Zaangażowanie w działalność publiczną, w tym między innymi w organizowanie akcji dobroczynnej, na pewno szło w parze $\mathrm{z}$ charyzmą miejscowego biskupa oraz zamożnością jego biskupstwa. Nie bez znaczenia była również zamożność miejscowego biskupa. Niestety, posiadamy tylko szczątkowe dane na temat stanu majątkowego ówczesnych biskupów. Te sprawy z reguły albo mało interesowały autorów późnoantycznych, albo też celowo były przez nich przemilczane. Wiedząc jednak, iż póżnoantyczni biskupi w sporej mierze wywodzili się z lokalnych notablów, stwierdzić można, iż dysponowali oni sporymi majątkami oraz odpowiednimi rezerwami gotówkowymi.

Na konieczność kontynuowania euergesji w miastach późnoantycznych złożyło się szereg uwarunkowań. Mimo iż w interesującym nas okresie na Wschodzie nie obserwujemy aż tak ostrych znamion kryzysu ekonomicznego, jaki odnotowujemy w tym czasie na Zachodzie, to jednak biorąc pod uwagę całościowy obraz gospodarki, wszechobecny fiskalizm, nie sposób nie zauważyć, iż polityka taka musiała pociągać za sobą negatywne skutki dla kondycji ekonomicznej wielu miast. Często przecież w źródłach późnoantycznych odnajdujemy utyskiwania na egzekutorów podatkowych, którzy bezlitośnie egzekwowali podatki ${ }^{24}$. Z kolei zubożenie miast stworzyło pole działania dla miejscowych notabli, którzy dostrzegali w niej okazję do bardziej aktywnego angażowania się w życie publiczne. Posiadany majątek, okazywanie swej szczodrości, nie były jednak wystarczającym atutem, aby zyskać wpływ na bieg spraw w swych miastach. W mieście ambitnych i żądnych władzy osób mogło być przecież wiele, a tylko jedna z nich mogła pokusić się o miejscowy tron biskupi, co wzmocniłoby jej pozycję nie tylko „moralnie”, ale i ,autorytatywnie" względem reszty notabli. Tak więc z pewnością to słaba kondycja ekonomiczna miast w późnej starożytności przyczyniła się do renesansu eurgesji, która stała się jednym ze sposobów nieformalnego przejmowania władzy w miastach przez euregetów, a przynajmniej dawało im pozycje nieformalnych liderów w ich społecznościach. Zjawisko nie jest więc nowe: kryzys form państwowych, spowodowany między innymi złym stanem gospodarki, zawsze działa destabilizująco na społeczeństwo i zawsze rodzi niebezpieczeństwo uaktywnienia się ambitnych jednostek, które w takiej sytuacji, wykorzystując do tego między innymi posiadany przez siebie majątek i koneksje, upatrywały okazję do zdobycia formalnej bądź też nieformalnej władzy w swym mieście.

Najpowszechniejszym przejawem euergezji była działalność fundatorska, która nie należała przecież do zwyczajowych funkcji biskupich. Jednakże biskupi często wywodzący się z miejscowych notabli, pod presją środowiska i nadal żywej tradycji euergesji, poczuwali się do obowiązku, wzorem swych pogańskich przodków, łożenia swych prywatnych pieniędzy na cele publiczne. Euer-

${ }^{24}$ Por. m.in. I. Milewski, Pieniądz w greckiej literaturze patrystycznej IV wieku (na przykładzie pism kapadockich Ojców Kościoła i Jana Chryzostoma), Gdańsk 1999, 54-65. 
getyzm był bowiem silnie zakorzeniony w miastach greckich na Wschodzie i nadal stanowił nieodłączny element życia codziennego.

1. Fundowanie oraz renowacja budowli użyteczności publicznej. Jedną $\mathrm{z}$ form uczestniczenia w życiu publicznym swego miasta była działalność biskupów na rzecz rozbudowy i modernizacji jego infrastruktury. Czasami to biskupi pełnili tu funkcję fundatorów. W wielu przypadkach jednak partycypowanie przez biskupów w kosztach budowy było skromne, albo nawet żadne, a ich rola ograniczała się jedynie do nadzorowania tej czy innej inwestycji. Poza tym ze źródeł epigraficznych, które chyba w największym stopniu informują nas o działalności budowlanej biskupów, nie zawsze jasno wynika, czy dany biskup był czy też nie był fundatorem budowli, na której kazał umieścić inskrypcję, w której mówi o sobie jako o jej budowniczym. Przykłady wznoszenia budowli użyteczności publicznej przez biskupów w przeważającej mierze pochodzą ze średnich i małych miast prowincjonalnych (choć są również wyjątki). Nieliczne informacje źródłowe pozwalają jednak na określenie skali przedsięwzięć, na które łożono środki finansowe. Finansowano przede wszystkim budowę bądź renowację murów miejskich ${ }^{25}$, mostów ${ }^{26}$, akweduktów ${ }^{27}$, budowę łaźni publicznych ${ }^{28}$, więzieni ${ }^{29}$, rozbudowę portów ${ }^{30}$, magazynów zbożo$w_{y c h}{ }^{31}$ oraz wiele innych budowli publicznych, których nie sposób tu wymienić. W wielu przypadkach źródła podają jedynie lakonicznie, iż ten czy inny biskup tylko zabiegał o renowację budowli publicznych, pozyskując na ten cel środki od cesarza bądź namiestnika ${ }^{32}$.

${ }^{25}$ Por. IGLS (Inscriptions grecques et latines de la Syrie) II 288 oraz D. Feissel, dz. cyt., s. 820821. Mury w Philae, por. E. Bernard, Les inscriptions grecques de Philae, II, w: Haut et Bas Empire, Paris 1969, nr 194-195; Gortyna na Krecie (A. Bandy, The Greek Christian Inscriptions of Crete, Athens 1970, s. 58-61 (nr 31) - rok najpewniej 539; zob. także IGLS II 270; XIII 9128 oraz 9130-9132.

${ }^{26}$ Por. Theodoretus, Epistulae: 79, 81, 139.

27 Dość obszerna dokumentacja źródłowa, por. m.in. przykład biskupa Kosmasa z Olbii w Izaurii, około 566 r. por. MAMA III 106. Cypryjska Salamina, por. T.B. Mitford, New Inscriptions from Early Christian Cyprus, „Byzantion” 20 (1950) 118-125 (nr 5). Firmianus, biskup Zenopolis - VI wiek, por. H. Delehaye, L'aqueduc de s. Socrate à Zénonpolis, „Analecta Bollandiana" 30 (1911) 316-320.

${ }^{28}$ Por. Placus, biskup Gerazy, jednego z miast Dekapolis: C. Kreling, Gerasa, City of the Decapolis, New Haven 1938; zob. także przykład z Palestyńskiego Scythopolis: M. Avi-Yonah, The Bath of the Lepers at Scythopolis, IEJ ("Israel Exploration Journal") 13 (1963) 325-326.

${ }^{29}$ Por. P.L. Gatier, Nouvelles inscriptions de Gerasa, ,Syria” 62 (1985) 298-307.

${ }^{30}$ Por. A. Avramea, dz. cyt., s. 833 (przypadek Stratona, biskupa na wyspie Skiatos).

31 Por. przykład Andrzeja, biskupa syryjskiej Aretuzy: IGLS V 2081.

32 Por. przyklad Ouraniosa, biskupa Trabzon: CIG IV 8636 oraz Jana, biskupa Bostry: IGLS XIII 9128-9134); zob. także działalność Euzebiusza, biskupa Tessalonik: J.M. Spieser, Les inscriptions de Thessalonique, ,Travaux et Mémoires” 5 (1973) 154; G. Dagron, Les villes dans l'Illyricum protobyzantin, w: Actes du Colloque organisé par l'École Francaise de Rome (1982), Rome 1984, 14-16. 
Absolutnym wyjątkiem było nadzorowanie przez biskupa budowy miasta od podstaw. Chodzi tu m.in. o mezopotamskie miasto Dara - Anastasiopolis, wybudowane za panowania cesarza Anastazjusza I, mające stanowić ważny punkt strategiczny w Mezopotamii. Cesarz namówiony do tej budowy przez swych dowódców, najpierw wykupił ową wieś Dara od jej właściciela Tomasza, biskupa Amidy. Dodatkowo jeszcze cesarz przekazał centnar złota na budowę kościoła w mającym powstać Anastasiopolis. Tomasz, biskup Amidy, nie tylko sprawował nadzór nad postępami prac, lecz również zarządzał środkami finansowymi, przeznaczonymi przez cesarza na tę inwestycję. Według Zachariasza Retora, miasto wybudowano w okresie „dwóch - trzech lat”, wyposażono we wszelkie budynki użyteczności publicznej oraz ustanowiono dla niego biskupa, niejakiego Eutychianosa, dotychczasowego prezbitera przy biskupie Amidy ${ }^{33}$.

Często w literaturze jako przykład mecenatu budowlanego biskupów, wskazuje się na działalność Teodoreta, biskupa Cyru. Teodoret nie był jednak euergetą w antycznym rozumieniu tego słowa, gdyż mimo, iż wybudował w swym mieście portyki, dwa mosty, łaźnie oraz wyremontował kilka budynków użyteczności publicznej, to jednak, jak sam nas szczerze zapewnia, inwestycje te finansował nie $z$ własnych funduszy, lecz z dochodów swego biskupstwa ${ }^{34}$.

Działalność niewielu biskupów - euergetów można tak dokładnie prześledzić, jak to się ma w przypadku Marcjana, biskupa Gazy, działającego w czasach Justyniana ${ }^{35}$. Pochodził z jednej z najwspanialszych rodzin w Gazie. Miał siedmioro rodzeństwa, spośród którego część wybrała karierę w administracji prowincjonalnej (jeden $\mathrm{z}$ jego braci był nawet przewodniczącym gazeńskiego buleterionu), część natomiast w hierarchii kościelnej (jego brat Anastazjusz został biskupem palestyńskiego Eleuteropolis). Marcjan zdobył również wspaniałe, jak na tamte czasy wykształcenie, między innymi u Prokopiusza z Gazy ${ }^{36}$. Zostawszy biskupem stał się, według Chorycjusza Retora, bardziej wpływowym niż lokalni urzędnicy. Jako biskup ujął się po raz pierwszy za mieszkańcami Gazy w okresie powstania Samarytan, kiedy to na obszarze Palestyny operowały liczne oddziały wojskowe. Biskup chcąc uchronić Gazę przed grabieżami i gwałtem ze strony wygłodniałych żołnierzy, zorganizował dla nich system aprowizacji, przez co oszczędził Gazie losu, jaki stał się udziałem sąsiednich miast ${ }^{37}$.

${ }^{33}$ Por. Zacharias Rhetor, HE VII 6; P. Collinet, Une „ville neuve” byzantine en 507: la fondation de Dara (Anastasiopolis) en Mésopotamie, w: Mélanges G. Schlumberger, I, Paris 1924, 55-60.

${ }^{34}$ Por. Theodoretus, Epistulae: 79, 81, 139.

35 Por. M.A. Meyer, History of the City of Gaza. From earliest Times to the Present Day, New York 1966, s. 66 (reprint wydania z 1907 roku).

${ }^{36}$ Por. Choricius Gazaeus, Oratio funebris in Marium 5, ed. R. Foerster - E. Richsteig, Stuttgart 1922.

37 Por. tenże, Laudatio Marciani II 24. 
Biskupa Marcjana widzimy również w roli ambasadora Gazy na dworze cesarza Justyniana; nie wiemy jednak, $\mathrm{z}$ jaką misją tam się udał ${ }^{38}$. Marcjan uczestniczył też we wznoszeniu budowli publicznych w Gazie: wybudował portyki przy głównych ulicach miasta oraz termy ${ }^{39}$, a także doprowadził do renowacji murów miejskich, które dodatkowo opatrzono wieżami i fosą. W naprawie murów miejskich wspólnie uczestniczyli biskup Marcjan, Stefanus - namiestnik Palestyny Pierwszej oraz kilku miejscowych notabli ${ }^{40}$.

2. Inne przejawy euergesji. Na uczestniczenie biskupów w życiu publicznym składają się także inne działania. Teodoret, kiedy został wybrany na biskupa, ściągnął ze swojej inicjatywy przedstawicieli zawodów, bez jakich mieszkańcy Cyru nie mogliby się obyć. Jednym z nich był bliżej nie znany nam kapłan Piotr, który zanim wstąpił w szeregi duchowieństwa, był lekarzem praktykującym w Aleksandrii ${ }^{41}$. Teodoret sprowadził do Cyru również różdżkarza, którego wiedzę wykorzystywał nie tylko przy swoich hydrologicznych przedsięwzięciach, lecz również pozwalał korzystać z jego usług sąsiednim miastom, szukającym dogodnie położonych i bogatych w wodę źródeł ${ }^{42}$.

Zachariasz Retor wychwala dbałość o sprawy swego miasta w przypadku Asklepiosa, biskupa Edessy. Według niego, biskup „pomagał swej gminie w wielu sprawach", spłacając nawet jej długi ${ }^{43}$.

Podtrzymywanie więc przez biskupów wspaniałych tradycji antycznej euergesji wiązało się z wydawaniem czasami sporych sum pieniężnych, z których miano finansować różnego rodzaju przedsięwzięcia. Jak wielkie sumy wydawano? Ta kwestia, choć bardzo istotna dla zrozumienia prezentowanego tu zagadnienia, musi jednak pozostać bez odpowiedzi: źródła bowiem nie podają nam kwot, jakie biskupi - euergeci wydawali na realizację swych przedsięwzięć.

3. Kontakty z urzędnikami. Czasami biskupi musieli brać w opiekę samą społeczność, której przewodzili. Były to tyleż uprawnienia formalne, wypływające $\mathrm{z}$ pełnienia określonych funkcji publicznych (jak chociażby defensora civitatis), jak również działanie będące skutkiem pełnienia przez nich funkcji pasterskich. Biskupi występując w imieniu swych owieczek przed urzędnikami, z pewnością liczyli na znaczenie powagi swego urzędu oraz fakt, iż przewodzili sporym rzeszom ludzi, w imieniu których mogli się wypowiadać, o interesy, których mogli również zabiegać. Ten więc zakres obowiązków i możliwości

\footnotetext{
${ }^{38}$ Por. tenże, Oratio funebris in Marium 21.

${ }^{39}$ Por, tenże, Oratio funebris in Proclum 52.

${ }^{40}$ Por. tenże, Laudatio Marciani I 7; II 16.

${ }^{41}$ Por. Theodoretus, Epistulae 114-115.

${ }^{42}$ Por. tenże, Epistula 37.

${ }^{43}$ Por. Zacharias Rhetor, HE VIII 4.
} 
działania był w tym przypadku ściśle związany z rolą polityczną, jaką poszczególni dostojnicy odgrywali we wczesnym Bizancjum.

Kwestia wstawiennictwa biskupiego u wysokich urzędników pojawia się w wielu listach autorów późnoantycznych. Wynika z nich, iż wielu biskupów interweniowało wówczas $\mathrm{w}$ obronie obywateli obciążanych nazbyt wysokimi podatkami; biskupi czasami zabiegali o pozostawienie dotychczasowego urzędnika na jego stanowisku, czasami wręcz przeciwnie, zabiegano o jego odwołanie. Informacje na temat tych interwencji odnajdujemy w listach Bazylego Wielkiego $^{44}$, Grzegorza z Nazjanzu ${ }^{45}$, Synezjusza z Cyreny ${ }^{46}$ oraz Teodoreta z Cyru ${ }^{47}$. Najczęściej więc to zwykła konieczność decydowała o tym, iż biskupi musieli utrzymywać stały kontakt $\mathrm{z}$ urzędnikami administracji każdego szczebla. Kontakty te były najbardziej widoczne w przypadku pasterzy średnich i małych miast. Wśród adresatów biskupiej korespondencji odnajdujemy urzędników prowincjonalnych, namiestników prowincji, urzędników przy prefekcie Wschodu, a czasami nawet osoby z najbliższego otoczenia cesarza.

4. Biskupi w roli ambasadorów swych miast. Interweniowanie na dworze cesarskim, odgrywanie w pewnym sensie przez biskupów roli ambasadorów swych miast, to kolejny przejaw późnoantycznej euergesji w wykonaniu biskupów. W miastach hellenistycznych i rzymskich na Wschodzie, ich wpływowi obywatele często podejmowali się różnego rodzaju misji na dworach panujących. Tradycja ta była praktykowana przez pogan również w późnej starożytności, a świadczy o tym między innymi przypadek Synezjusza z Cyreny, który nie będąc jeszcze biskupem, w 399 r. został wysłany przez swoje miasto z misją do Konstantynopola, na dwór cesarza Arkadiusza ${ }^{48}$.

Dlaczego jednak biskupi podejmowali się takich zadań, mimo iż miasta posiadały swych włodarzy? Najprawdopodobniej to sprawowanie nieformalnej funkcji lidera miasta nakazywało biskupom w razie potrzeby ująć się za jego interesami, wyprosić zwolnienie od uciążliwego obowiązku bądź obniżenie wysokości podatku.

O jednej z takich misji donosi nam Jan z Efezu: mianowicie Stefanowi, biskupowi jednego z cypryjskch miast, udało się na dworze w Konstantynopo-

${ }^{44}$ Por. Basilius, Epistulae: 21, 37, 83, 85, 88, 96, 104, 107-110, 303; M.F. Patrucco, Aspetti del fiscalismo tardo - imperiale in Capadocia: la testimonianza di Basilio di Cesarea, „Atheneum” 51 (1973) 294-309.

${ }^{45}$ Por. Gregorius Nazianzenus, Epistulae: $67-69,98$.

${ }^{46}$ Por. Synesius, Epistulae: 57-58, 72-73, 79; także J. Vogt, Synesios gegen Andronicos, w: Adel und Kirche. Festschrift G. Tellenbach zum 65. Geburtstag, hrsg. von J. Fleckenstein - K. Schmid, Freiburg im Breisgau 1968, 15-25; S. Vollenweider, Synesius, s. 233; W. Cramer, Zur Entwicklung der Zweigewaltenlehren. Ein unbeachter Beitrag des Synesios von Kyrene, RQ 72 (1977) 43-56.

${ }^{47}$ Por. Theodoretus, Epistulae: 39-40, 42-47; tenże, Historia religiosa 14, 4.

48 Por. Synesios, Epistula 95; zob. także H.G.W. Liebeschuetz, Synesius and Municipal Politics of Cyrenaica in the $5^{\text {th }}$ Century A. D., „Byzantion” 55 (1985) 146nn. 
lu uzyskać obniżenie wysokości podatków ściąganych z wyspy ${ }^{49}$. Podobnie było również w przypadku misji Indakosa, biskupa Korcyry ${ }^{50}$. Z bliżej nie znaną nam misją do stolicy w czasach Justyniana udał się również Marcjan, biskup $\mathrm{Gazy}^{51}$. Nie wszystkie jednak misje kończyły się powodzeniem. Tak było między innymi w przypadku podróży Piotra, biskupa Edessy, który udał się do cesarza Anastazjusza I (ok. 500 r.), aby prosić go o obniżenie wysokości podatków, jakie jego miasto miało wpłacić do kasy cesarskiej. Misja biskupa Piotra zakończyła się jednak niepowodzeniem i dopiero starania miejscowego Hegemona Aleksandra przyniosły pożądany skutek ${ }^{52}$. Czasy Justyniana przyniosły nawet pewne udogodnienia dla takich podróży. W jednej z nowel cesarz wręcz nałożył na biskupów obowiązek osobistego informowania go o niepokojących zjawiskach w prowincjach ${ }^{53}$. W roli ambasadora swych miast do stolicy udawali się również duchowni niższego szczebla ${ }^{54}$, a nawet mnisi ${ }^{55}$.

Najbardziej znanym przykładem misji biskupa w roli ambasadora swego miasta jest mediacja, jakiej w 387 roku podjął się biskup Flawian, który udał się do stolicy w obronie Antiochii i jej mieszkańców. Biskup chciał uchronić miasto przed represjami, jakie niechybnie dotknęłyby miasto za wzniecenie buntu i odmowę zapłacenia bliżej nie określonego w źródłach podatku narzuconego Antiochii przez cesarza Teodozjusza Wielkiego. Podpalono wówczas siedziby urzędników, powywracano posągi pary cesarskiej, po czym zarzucono na nie liny i wleczono po mieście. Gawiedź miejska nie szczędziła przy tym parze cesarskiej wyzwisk. Pacyfikacji miasta zapobiegła tylko skuteczna mediacja, jakiej podjął się biskup Flawian ${ }^{56}$.

\section{Troska o porządek publiczny oraz organizowanie obrony miast przed} najazdami. Wśród wielu zadań, jakie przyszło wypełniać biskupom w późnej starożytności było również dbanie o bezpieczeństwo w swych miastach. O takim przypadku czytamy w Kronice Edeskiej, z której dowiadujemy się, iż biskup

${ }^{49}$ Por. Johannes Ephesinus, HE II 3.

50 Por. MAMA III 197.

51 Por. Choricius Gazaeus, Oratio funebris in Marium 21.

52 Por. Josua Stylites, The Chronicle of Joshua of Stylite 39, 42, 78, ed. W. Wright, Cambrigde 1882.

53 Por. Novellae Iustniani CXXIII 26.

${ }^{54}$ Por. Zacharias Rhetor, HE VII 1 (przykład misji prezbitera Jana z Amidy w czasach cesarza Zenona).

${ }_{55}$ Por. Cyrillus Scythoplitanus, Vita Sabae 51 i 71.

56 Por. Joannes Chrysostomus, Ad populum Antiochenum hom III, PG 49, 47-60; Sozomenus, HE VII 23; Theodoretus, HE V 20; G. Downey, A History of Antioch in Syria from Seleucus to the Arab Conquest, Princeton 1961, 426-433; R. Browning, The Riot of A. D. 387 in Antioch: the Role of the Theatrical Claques in the Later Roman Empire, ,,Journal of Roman Studies” 42 (1952) 13-20; F. van de Paverd: St. John Chrysostom, The Homilies on the Statues, Roma 1991, 122-160. 
Edessy w połowie $\mathrm{V}$ wieku, dbając o bezpieczeństwo w mieście zorganizował oddziały milicji, które nocami patrolowały ulice ${ }^{57}$.

Czasami jednak należało również stawić czoła najazdowi z zewnątrz i przygotować miasto do obrony. Powszechnie znany jest przykład Synezjusza, biskupa Ptolemaidy, który zorganizował obronę swego miasta przed najazdami koczowników. Biskup rzekomo do tego stopnia zaangażował się w obronę swego miasta, iż nie tylko nocą osobiście patrolował posterunki na murach, lecz również sam trzymał straż ${ }^{58}$. O podobnym działaniu źródła donoszą również w przypadku biskupa Philae ${ }^{59}$ oraz biskupa Tesalonik, który w 479/80 obronił miasto przed splądrowaniem go przez Teodoryka i jego Gotów ${ }^{60}$.

Biskupi podejmowali się również niekiedy roli mediacyjnej w konflikcie z najeźdźcami. Skutkiem takiej mediacji było najczęściej uchronienie miasta przez grabieżą. W taki sposób Tomasz, biskup syryjskiej Apamei, uchronił swe miasto przed szturmem Persów wypłacając im tysiąc funtów srebra ${ }^{61}$; podobnie było również w przypadku działań biskupów Sury ${ }^{62}$ oraz Beroi $^{63}$. Biskupi w roli mediatorów swych miast pojawią się również w okresie ekspansji arabskiej w VII wieku ${ }^{64}$.

$\mathrm{Z}$ rozważań zamieszczonych w niniejszym artykule można by wysnuć błędny wniosek, iż miasta prowincjonalne w interesującym nas okresie były pozostawione przez cesarzy swojemu losowi, a o ich interesy mieli dbać tylko lokalni biskupi. Wyżej opisana działalność biskupów nie była jednak regułą, a wiele miast miało za swych pasterzy ślamazarnych biskupów, mając jednak przy tym dbających o nie urzędników. Tak jak w przypadku budowli publicznych o charakterze lokalnym (w tym również mury miejskie) ${ }^{65}$, cesarze wymagali, aby ich renowacja czy nawet budowa finansowana była z dochodów miast; tak już na budowę, czy też renowację budowli poza obrębem murów miejskich, jak na przykład akweduktów, dróg czy mostów, łatwiej można było uzyskać środki na ten cel od cesarza ${ }^{66}$. Poza tym także miasta mogły liczyć na specjalną pomoc

57 Por. Chronik von Edessa 68, ed. L. Hallier, TU IX 1, Leipzig 1892.

58 Por. Synesios, Epistulae 88 i 131; Ch. Lacombrade, Synésios de Cyrène, Hellène et Chrétien, Paris 1951, 76nn; R.G. Goddschild, Synesius of Cyrene: Bishop of Ptolemais, w: R.G. Goodschild, Libyan Papers, ed. by J. Reynolds, London 1976, 248nn; H. Kraeling, Ptolemais, City of the Libyan Penatapolis, Chicago 1962, 24.

59 Por. G.I. Bratianu, Privilèges et franchises municipales dans l'Empire Byzantin, Paris Bucaresti 1937, 74nn.

${ }^{60}$ Por. A. Hohlweg, Bischof und Stadtherr im frühen Byzanz, ,Jahrbuch der Österreichischen Byzantinistik" 20 (1971) 57.

${ }_{61}$ Por. Prokopios, De bello Persico II 11, ed. H. B. Dewing, London 1914.

${ }^{62}$ Por. tamze II 5.

${ }^{63}$ Por. tamze II 6.

${ }^{64}$ Por. relacje Theophanesa, Chronicon: 6127, 6140-6141, 6200.

65 Por. chociazby C J I 4, 26; Novellae Iustiani CXXVIII.

${ }^{66}$ Por. Novellae Iustiani XXIV 3; XXV 4, 1; XXVI 4, 1. 
finansową od cesarza przy usuwaniu szkód powstałych na skutek kataklizmu, na przykład trzęsienia ziemi ${ }^{67}$. Dzięki Kronice Jozuego Stylity, dobrze znany jest przykład aktywności urzędników w Edessie na przełomie V i VI wieku. Jozue wychwala działalność miejscowych hegemonów, Aleksandra i Demosthenesa ${ }^{68}$ oraz Eulogiosa, namiestnika Mezopotamii ${ }^{69}$.

\section{UWAGI KOŃCOWE}

W interesującym nas okresie działalność lokalnych notabli na polu euergesji, było jednym ze sposobów powiększania przez nich wpływów w swych miastach. Wykładając czasami niebagatelne sumy, kupowali oni sobie tym samym w sposób niekontrolowany władzę w swych miastach. Dobrze było jeszcze wzmocnić ją o powagę urzędu biskupiego. Nie przypadkiem więc na tronach biskupich w wielkich i średnich miastach widzimy wówczas miejscowych notabli, czasami nawet byłych urzędników prowincjonalnych. Ów klasyczny sposób pojmowania roli bogatych obywateli był więc nadal żywotny w mentalności późnoantycznych notabli, czasami wywodzących się z chrześcijańskich rodzin, najczęściej jednak chrześcijan z wyboru, a czasami z wyrachowania bądź przymusu.

Dlaczego za swych pasterzy często chciano mieć ludzi zamożnych? Wiedziano, iż są to ludzie mający pewne koneksje na szczeblach władzy; nie bez znaczenia musiało być również przekonanie o tym, iż tacy właśnie biskupi nie będą „oglądać się” na zasobność kasy biskupiej, a w razie potrzeby sięgną również do własnych rezerw finansowych. Rozmach działalności dobroczynnej oraz skala uczestniczenia biskupa w życiu publicznym, jego finansowe możliwości partycypowania w kosztach utrzymania miasta, decydowały przecież o poziomie życia wielu mieszkańców miast. Dla notabla natomiast uzyskanie tronu biskupiego było równoznaczne z uzyskaniem szerokiego pola do działania. Sprawowanie funkcji biskupa było wówczas ze wszech miar atrakcyjne, a pod względem znaczenia i posiadanych wpływów, biskupi nawet niewielkiego miasta mogli się równać wysokim urzędnikơm w prowincji. O atrakcyjności sprawowania urzędu biskupiego w interesującym nas okresie świadczy fakt, iz pewne grupy zawłaszczyły sobie prawo do obsadzanie tronów biskupich w późnej starożytności. W literaturze omawiającej to zjawisko mówi się o realizowaniu przez tego czy innego ambitnego dostojnika ,polityki kościelnej".

${ }^{67}$ Por. przykład Myry i Laodikei dotkniętych w czasach Justyniana trzęsieniem ziemi: Malalas, Chronographia XVIII, ed. L. Dindorf, Bonnae 1831, p. 448. Analogiczne przypadki zob. tamże XVII, p. 424; XVIII, p. 436, 443-444.

${ }^{68}$ Por. Josua Stylites, The Chronicle 29 i $42-43$.

${ }^{69}$ Por. tamze, 87. 
W miastach późnoantycznych, i to nie tylko na Wschodzie, lecz również na Zachodzie, zaistniała sytuacja, w której zarysował się widoczny podział pomiędzy tymi, którzy władzę w miastach sprawowali z urzędu oraz biskupami, którzy sprawowali ją w sposób nazwijmy to nieformalny, dzięki przewodzeniu licznej rzeszy chrześcijan, prowadzeniu akcji dobroczynnej oraz działaniu na rzecz polepszenia infrastruktury miast. W wielu przypadkach późnoantyczni biskupi stali się de facto zarządcami miast, nie sprawując w nich żadnych urzędów publicznych. O znaczeniu urzędu biskupa w interesującym nas okresie świadczy uwaga w. Liebeschuetza, który utrzymuje, iż w VI wieku większość cesarskich rozporządzeń kursowało nie via cesarz - namiestnik - kuria, lecz cesarz a poszczególni biskupi ${ }^{70}$.

Wznoszenie oraz renowacja budowli użyteczności publicznej, bądź nawet tylko organizowanie funduszy na te przedsięwzięcia, organizowanie świąt religijnych, rozdawnictwa żywności i pieniędzy oraz asygnowanie sporych sum pieniężnych na zakup zboża, to najczęstsze przejawy antycznego euergetyzmu nadal praktykowanego w późnej starożytności przez biskupów. Poza oczywiście nowatorskim charakterem chrześcijańskiej caritas (szczególnie w przypadku organizacji rozdawnictw), nie dostrzegamy jakichś szczególnych różnic pomiędzy działalnością antycznych - pogańskich eurgetów, a praktykującymi podobne działania późnoantycznymi biskupami. Inna była oczywiście oprawa ideologiczna, cała reszta, owe obszary aktywności, którą moglibyśmy nazwać obywatelską, pozostała niezmieniona. Pewne elementy antycznej, pogańskiej euergesji, z oczywistych względów bądź nie mogły być już kontynuowane (jak chociażby organizacja igrzysk), bądź też uległ zmianie ich charakter (finansowanie świąt). Nie zarzucono również dawnego zwyczaju organizowania uczt publicznych. Pewne budowle, jak na przykład gimazjony, nimfea, tetary, stadiony czy też świątynie, z oczywistych względów nie były już fundowane. W ich miejsce finansowano budowę kościołów, kaplic męczenników oraz instytucji dobroczynnych.

Z pewnością jednak znajdą się tacy, którzy stwierdzą, iż antycznymi, pogańskimi euergetami, w odróżnieniu od podobnie działających biskupów, kierowała chęć utrwalenia swego imienia i czynów w pamięci społeczności, z której się wywodzili. Co w takim razie powinniśmy powiedzieć o biskupach, którzy o wznoszeniu przez siebie budowli publicznych informowali w swych listach urzędników lub też budowle te opatrywali odpowiednimi inskrypcjami? ${ }^{71} \mathrm{Ta}$ kie to były czasy, a późnoantyczni biskupi, pochodzący nierzadko z miejscowych notabli, byli przede wszystkim ludźmi swojej epoki, silnie osadzeni w tradycji praktykowania euergezji, której jednym z celów było zaskarbienie

${ }^{70}$ Por. Liebeschuetz, The Rise, s. 120.

${ }^{71}$ Faktem jednak jest, iz na wielu z tych inskrypcji brak imion własnych biskupów. Wyjątek stanowi kilka inskrypcji z Syrii, por. IGLS II 458-460; 477; IV 1582, 1607. 
sobie wdzięczności u społeczności, dla której podejmowano konkretne działania.

Pamiętajmy, iż piastowanie pewnych funkcji publicznych przez biskupów $\mathrm{w}$ interesującym nas okresie wynikało z przyzwolenia panujących. Pozostaje oczywiście pytanie, jak biskupi wywiązywali się z tych funkcji. Jako, ze w ustawodawstwie cesarskim nie znajdujemy żadnych informacji wskazujących na niemrawość w ich pełnieniu przez biskupów, przyjąć można, iż z zadań tych (może jedynie poza działalnością sądowniczą) wywiązywali się oni poprawnie, co w wielu przypadkach było związane z tym, iż wcześniej wielu $\mathrm{z}$ nich sprawowało pewne funkcje w administracji prowincjonalnej. Działalność publiczna biskupów późnorzymskich na pewno przyczyniła się również do odciążenia administracji prowincjonalnej, a tym samym wpłynęła również korzystnie na usprawnienie jej działalności.

Czy dochodziło do scysji pomiędzy urzędnikami a biskupami ingerującymi w coraz większym stopniu w życie publiczne? Oczywiście, a świadczą o tym korespondencja Bazylego Wielkiego, Grzegorza z Nazjanzu oraz Synezjusza z Cyreny. Ten ostatni toczył z urzędnikami istne boje, przede wszystkim $\mathrm{z}$ namiestnikiem Andronikosem, doprowadzając z czasem nawet do utraty przez niego urzędu ${ }^{72}$. Innym przykładem są nie najlepsze stosunki pomiędzy, ariańskim biskupem Aleksandrii Jerzym, a miejscowymi urzędnikami ${ }^{73}$.

Czy dostrzegamy jakieś konkretne różnice pomiędzy znaczeniem urzędu biskupiego na Zachodzie i na Wschodzie w interesującym nas okresie w zakresie odgrywanej przez nich roli w życiu publicznym? Oczywiście, a stan taki był uwarunkowany przede wszystkim odmienną sytuacją polityczną, społeczną i gospodarczą obydwu części Imperium. Te szczególne uwarunkowania na Zachodzie przyczyniły się do większego wzrostu potęgi politycznej tamtejszych biskupów (nawet pasterzy niewielkich miast), ich majątków oraz ugruntowania się zjawiska tak zwanych dynastii biskupich, kiedy to synowie zasiadali na tronach biskupich po śmierci swych ojców, wujów, czy też dalszych krewnych ${ }^{74}$.

Co więc decydowało o kontynuowaniu przez biskupów antycznego modelu euergesji w miastach wczesnochrześcijańskich? Szereg czynników, wśród których wymienić możemy nakazy pozycji społecznej oraz nadal żywy patriotyzm obywatelski. Czy praktykowanie euergezji było kluczem do zdobycia władzy w miastach? Tu z pewnością zdania będą podzielone, choć autor niniejszego artykułu uważa, że tak, a przynajmniej w wielu przypadkach działania takie umożliwiały, czy wręcz ułatwiały osiągnięcie miejscowego tronu biskupiego. Choć w źródłach akcentuje się, co prawda, również znaczenie walorów moral-

${ }^{72}$ Por. M.B. Leszka, Rola duchowieństwa na dworze cesarzy wczesnobizantyńskich, Łodź 2000, 108-109.

73 Por. Sozomenus, HE IV 30.

${ }^{74}$ Por. chociażby G. Scheibelreiter, Der Bischof in merovingischer Zeit, Wien - Köln - Graz 1983. 
nych kandydatów na urząd biskupi, ich pobożność itp., to jednak nie przeceniałbym poziomu świadomości ówczesnych chrześcijan, iż za swych pasterzy chcieli mieć tylko osoby legitymujące się właściwym morale. Opinie te powinniśmy bardziej postrzegać jako opinie samych autorów tych pism, którzy chcieli tym samym upowszechnić pewien rzadko jednak osiągalny ideał kapłana.

Jakie natomiast były skutki aktywnego uczestniczenia biskupów w życiu publicznym w interesującym nas okresie? Wymienić ich można kilka, począwszy od wzrostu ich roli politycznej i społecznej, a skończywszy na zyskaniu przez nich pozycji nieformalnych liderów lokalnych społeczności. O odgrywaniu pewnej roli politycznej możemy jednak mówić przede wszystkim w przypadku pasterzy wielkich miast, jak chociażby arcybiskupa Konstantynopola czy Aleksandrii. Z pewnością nie bez znaczenia była tu również osobista charyzma tego, czy innego dostojnika kościelnego. Jakich inicjatyw politycznych podejmowali się późnoantyczni biskupi i z jakim skutkiem? Inicjatywy, z jakimi występowali biskupi były różne, począwszy od mediacji w tym czy innym konflikcie (klasycznym jest tu przykład mediacji Jana Chryzostoma w przypadku buntu Gota Gainasa $^{75}$ ), po próby wywierania wpływu na aktualnie realizowaną politykę państwa.

Wzrost znaczenia urzędu biskupiego w interesującym nas okresie pociągnął za sobą również zintensyfikowanie procesu chrystianizacji, a co za tym idzie coraz częstsze wypieranie pogan z urzędów publicznych. Pod wieloma więc względami rola biskupa w mieście późnoantycznym stanowiła kontynuację fundamentalnych zasad ustrojowych panujących w miastach cywilizacji grecko-rzymskiej, w których funkcje publiczne, a taką niewątpliwie ze względu na swój charakter był w późnej starożytności również urząd biskupa, sprawowane były przez najbogatszych, co z kolei związane było również z koniecznością partycypowania w kosztach utrzymania miasta, dbania o jego budowle publiczne, dostarczanie wody pitnej oraz przychodzenie z pomocą potrzebującym. Był to model aktywności obywatelskiej, praktykowany od wieków na Wschodzie. Dostrzegamy jednak również zjawisko, które przekreślało wcześniejszy porządek panujący w miastach: lokalne społeczności zaczęly wybierać na swych pasterzy w późnej starożytności również ludzi wywodzących się z dolnych warstw społeczeństwa.

Chcąc zdefiniować rolę biskupa w mieście późnoantycznym, można powiedzieć, iż na tle całej epoki starożytnej, zjawisko to urosło do rangi swoistego fenomenu. Mamy tu bowiem do czynienia z symbiozą modelu antycznego notabla, wypełniającego nakazy obywatelskiego patriotyzmu, z nowym wzorcem postawy lansowanym przez chrześcijaństwo, męża mającego cechować

75 Por. Sozomenus, HE VIII 4; Socrates, HE VI 6; Theodoretus, HE V 33; zob. także J.H.W.G. Liebeschuetz, Barbarians and Bishops. Army, Church and State in the Age of Arcadius and Chrysostom, Oxford 1992, 104nn. 
wysoki poziom moralności oraz troska o potrzebujących. Pod wieloma względami jednak sprawowanie funkcji biskupich w interesującym nas okresie, nadal związane było $\mathrm{z}$ kontynuowaniem antycznego modelu euergesji.

\section{EINIGE BEMERKUNGEN ÜBER DIE ROLLE DES BISCHOFS IN DER SPÄTANTIKEN STADT (am Beispiel der oströmischen Provinzen)}

\section{(Zusammenfassung)}

In diesem Beitrag wurde die Rolle des Bischofs in der spätantiken Stadt besprochen. Die Aufmerksamkeit des Verfassers wurde vor allem auf eine Frage gelenkt: kann man die öffentliche Tätigkeit des spätantiken Bischofs als eine Fortsetzung der antiken Euergesia betrachten? Der Autor dieses Aufsatzes ist der Meinung, daß ja. Die Beantwortung dieser Frage stellen sich jedoch viele Schwierigkeiten entgegen, vor allem durch die Lakonität der Quellen, die die Tätigkeit der einzelnen Bischöffe betrifft.

Der Bischof war ohne Zweifel das politische Oberhaupt der spätantiken Stadt, obwohl er kein öffentliches Amt im Rahmen eines Gemeinwesens bekleidete. Die soziale und kommunale Tätigkeit der spätantiken Bischöffe ist in vielen Fällen sehr gut dokumentiert; besonders wichtig und maßgebend sind die papirologischen und epigraphischen Quellen. Die Tätigkeit des Bischofs im Rahmen der spätantiken Stadt geschieht teils spontan, teils aber auch in Folge der kaiserlichen Gesetzgebung, die manchmal ermöglichte, manchmal aber auch zwang die Bischöffe zur Aktivität in verschiedenen Lebensbereichen der spätantiken Staat. Der Bischof gewann eine große politische Rolle im 4. und 5. Jahrhundert auch in Folge dessen, daß er auch ein Repräsentant und Führer der Gemeinde der Gläubigen war und deswegen wurde er mehr und mehr in den staatlichen Bereich einbezogen.

Im Folge der allmählichen Stärkung des Bischofsamtes in der Spätantike übernahmen die Bischöffe, als die Stadtpatrone, viele von den innerstädtische Aufgaben. Der spätantike Bischof scheint uns als ein „Vater” und Beschützer der Stadt (z. B. vor Übergriffe der Stcuerbeamten und manchmal auch Gouverneure der Provinz). $\mathrm{Zu}$ ihm gehörte auch die Aufsicht über Finanzen der Stadt, darin auch die Aufsicht über die Verteilung des einkommenden Gelde). Wir sehen den Bischof auch als einen Wohltäter und Stifter der öffentlichen Gebäuden (Thermen, Wasserleitungen, Bäder, Brücken, Speichern, Stadtmauern). Der spätantike Bischof besaß auch die richterlichen Kompetenzen. Das Amt des Bischofs erfreute sich in dieser Zeit eine große Wertschätzung. Der Bischof, obwohl er als Leiter eines Gemeinwesens betrachtet wurde, pflegte jedoch kein öffentliches Amt im Rahmen der Stadt. Der spätantike Bischof verkörperte eine religiöse und weltliche Interessensphären. Deswegen auch spricht man manchmal über ein Phänomen des Bischofsamtes in der Spätantike. 